\title{
A GEOTECTONIC VIEW OF THE RIBEIRA AND DOM FELICIANO BELTS
}

\section{PAULO C. SOARES ${ }^{1}$, ALBERTO P. FIORI ${ }^{1}$, LUIGI CARMIGNANI ${ }^{2}$ AND SIDNEY P. ROSTIROLLA ${ }^{1}$}

\begin{abstract}
The Ribeira and Dom Feliciano collision belts are constituted of many overthrust bounded entities, some of them with very different stratigraphic record. They were intensively modified by large transcurrent faults. Two supercycles, one Mesoproterozoic and the other Neoproterozoic, has been recognized in the evolution of the belts, mainly based on the study of the meta-sedimentary complexes. The Mesoproterozoic records a segmented sedimentary basin supercycle and metamorphism; in early Neoproterozoic the convergence zone was stretched and collapsed and the basins evolved through a complete sedimentary supercycle. Inversion is indicated by collisional granites from $750 \mathrm{Ma}$, culminating with strong deformation, closure of basins, metamorphism and allochthons formation in mainly frontal collision around $650 \mathrm{Ma}$. Flexural marine molasse basins were formed during Vendian. New inversion was produced by strong convergence and lateral movement of blocks, subcontinental mantle and crustal fusion, late tectonic migmatite and granite intrusions (600-560 Ma). Later on (540-490), alkaline granite intrusion affected many environments, felsic volcanism and continental sedimentary rocks accumulated in many extensional zones and graben-like basins. Syngenetic massive sulfide polymetallic exhalative mineralization is common in the Mesoproterozoic supercycle terranes, while in the Neoproterozoic the common mineralization are epigenetic $\mathrm{Pb}-\mathrm{Zn}$ massive sulfides in limestones and $\mathrm{Cu}-\mathrm{Zn}-\mathrm{Pb}$ in terrigenous sediments.
\end{abstract}

Keywords: collision belts, Brazil Precambrian terranes, Ribeira belt

INTRODUCTION A review and a reinterpretation of evolution of the Proterozoic Ribeira (southeast Brazil) and Dom Feliciano (southern Brazil and Uruguay) mobile belts are made, based fundamentally on the analysis of the sedimentary and tectonic record of the two belts. Long term field work has been carried out by the authors mainly in the Ribeira valley (Paraná and São Paulo) and in the Itajaí Mirim valley (Santa Catarina), followed by field trips in Rio Grande do Sul and Uruguay.

The main hypotheses defended in this work are coherent with the following conceptions, some of them previously presented, but conflicts with some current interpretation of the evolution of those belts (e.g. Fragoso-Cesar 1991, Fernandes et al.1992):

First, the Dom Feliciano and Ribeira belts in the states of Paraná and Santa Catarina are separate by the Joinville continental fragment, now constituted by the Luís Alves, Curitiba and south part of São Paulo (Juquiá) blocks. This intermediary Joinville continental element pinches out under the Basin of Paraná and the two belts join in one only belt that continues at least to Uruguay.

Second, the western margin of the belt is constituted by the paleocontinent Rio de la Plata - Paraná, while the eastern continental margin, affected by the Dom Feliciano belt - is the microcontinent Pelotas-Walvis, which intervenes among the Dom Feliciano arm and the African Gariep and Damara belts, and not a collision between Kalahari and Rio de La Plata.

Third, the Ribeira and Dom Feliciano belts were developed during two supercycles; the first, of Mesoproterozoic age, is characterized predominantly by the continental rifting to ocean basin followed by volcanic arc development, convergence and metamorphism, without continent-continent collision. The second, Neoproterozoic, is characterized by crustal stretching and collapsing of the previous belt, basin reopening, ocean basin, arc and back arc basin development.

CONTINENTS, MICROCONTINENTS AND TERRANES In the Ribeira and Dom Feliciano belts one distinguishes: early Paleozoic basins, Neoproterozoic basins, strips of Meso and Neoproterozoic metamorphites, batholithic complex and the old continental blocks. The illustration in Fig. 1 represents an attempt at evidencing the main structural elements, leaving out the granite intrusions of the end of Brasiliano cycle. These belts are shown in the context of the extensive collage of continents in the end of Proterozoic (a). The main figure shows the terranes involved in the collision and the correlated ones along the belts. The sense of transport of orogenic metamorphic allochthons and of the late collision tectonic escape is shown in the inset (b)

Geophysical data indicates that the Ribeira Belt is extended southwestward under the Paraná Basin until Uruguay (Soares et al. 1998) joining to the Dom Feliciano belt (Fig. 2). A strip of gravimetric lows marks the collision belts due to the prism of accreted volcanosedimentary and granite rocks aside high values characteristic of deeply eroded crust of early continental blocks exposed in the frontal bulges (Fig. $2 \mathrm{c}$ and d). Using these gravimetric elements together with lithologic and structural data, a new picture for belts and crustal blocks was drawn. The frontal bulges are present just aside the main zone of suture and are marked by high gravimetric values in many belts, due to the uplift of early dense crustal segments.

The Joinville continental terrane (Joinville massif, from Hasui et al 1975), figures out as a lithospheric fragment, formed by the Juquiá (southern São Paulo), Curitiba and Luís Alves blocks, that pinches out bellow the Paraná cover and is not an extension of Rio de la Plata Craton (Figs. 1 and 3)(Soares e Rostirola 1997). The east side of Dom Feliciano belt is conceived as another continental block, the Pelotas Walvis microcontinent, mainly because of gravimetric high values and due to Archean isotopic heritage (Hartmann et al. 1998) and the existence of early Paleoproterozoic inliers in its counterpart, in Namibia (between Walvis and Windoek; Thomas et al. 1993).

LITHOLOGIC AND KINEMATIC CORRELATION In all these metamorphic belts four different associations of rocks can be identified, taking into account protolith, metamorphic zoning and deformational fabrics: two different metamorphic complexes associations an two sedimentary and volcanic associations.

The differences among the rocks of the first and second metamorphic complexes, are known since a long time (Reis Neto and Soares 1987; Basei 1985; Jost and Bitencourt 1980). These complexes are described and correlated briefly ahead, in order to highlight the similarities among them. The designations used are mainly from Preciozzi et al. (1993), Jost and Bitencourt (1980), Basei (1985), Soares (1987), Fiori (1993) and Juliani and Beljavskis (1995). The spatial position and geometric relationship among the several complexes, their terranes, and the preserved sedimentary basin are represented in the cross sections of Fig. 3.

The Lower Metamorphic Complexes. In the lower metamorphic complexes, schists, quartzites and marbles of greenschist, biotite zone, to amphibolite facies, sillimanite zone, occurring extensively syn - and pre-kinematic garnets. Quartzite, ortho-amphibolite, schist and marble disrupted bodies are common in the lower part of the section, followed by protoliths with abundant volcanic contribution, chert-iron and marls-manganese formations. The upper units is composed of schists derived from immature rocks, wackes, volcanics and plagioclasearenites. Post-metamorphism intrusive dolerites (1000 to $1050 \mathrm{Ma}$; Reis Neto 1994) are frequent. The fabric is formed by a schistosity associated to ductile deformations and regional metamorphism (D1, M1) which does destroy the original bedding. The schistosity is deformed in varied degrees, and almost entirely transposed by a phyllonitic foliation (D2, M2), forming low to high angle shear bands, with retrometamorphism. A third crenulation cleavage may be present, associated with fault or folding. These complexes appear in the lower level of tectonic stratigraphic allochthons, in tectonic windows around the nuclei of the front bulges, and in the margins of the uplifted magmatic arches or batholithic complexes. They are present in all the metamorphic strips receiving local and regional names, like Itapira, Serra de Itaberaba, Setuva, Perau, Agua Clara, Botuverá, Cerro da 


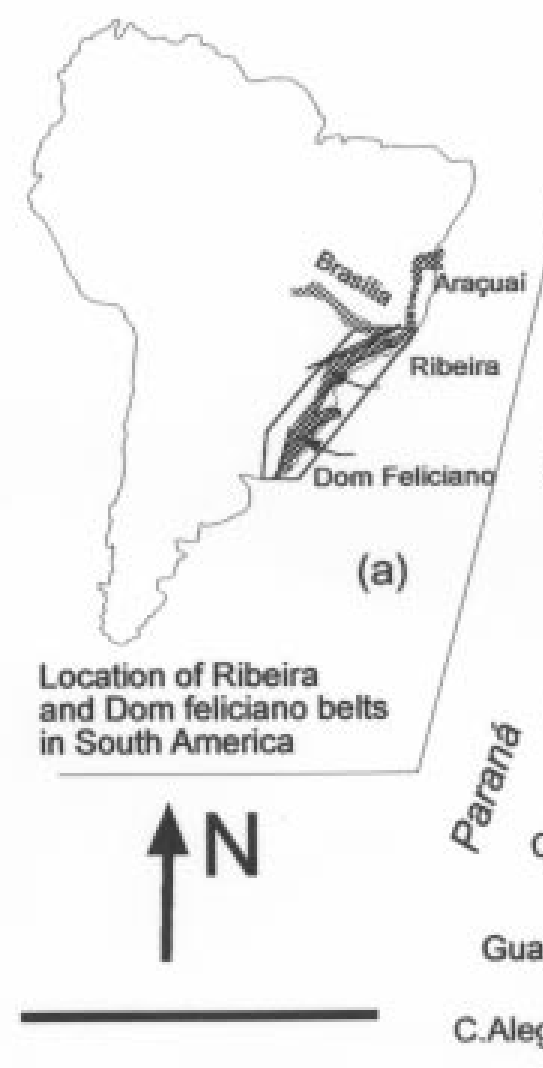

$250 \mathrm{~km}$

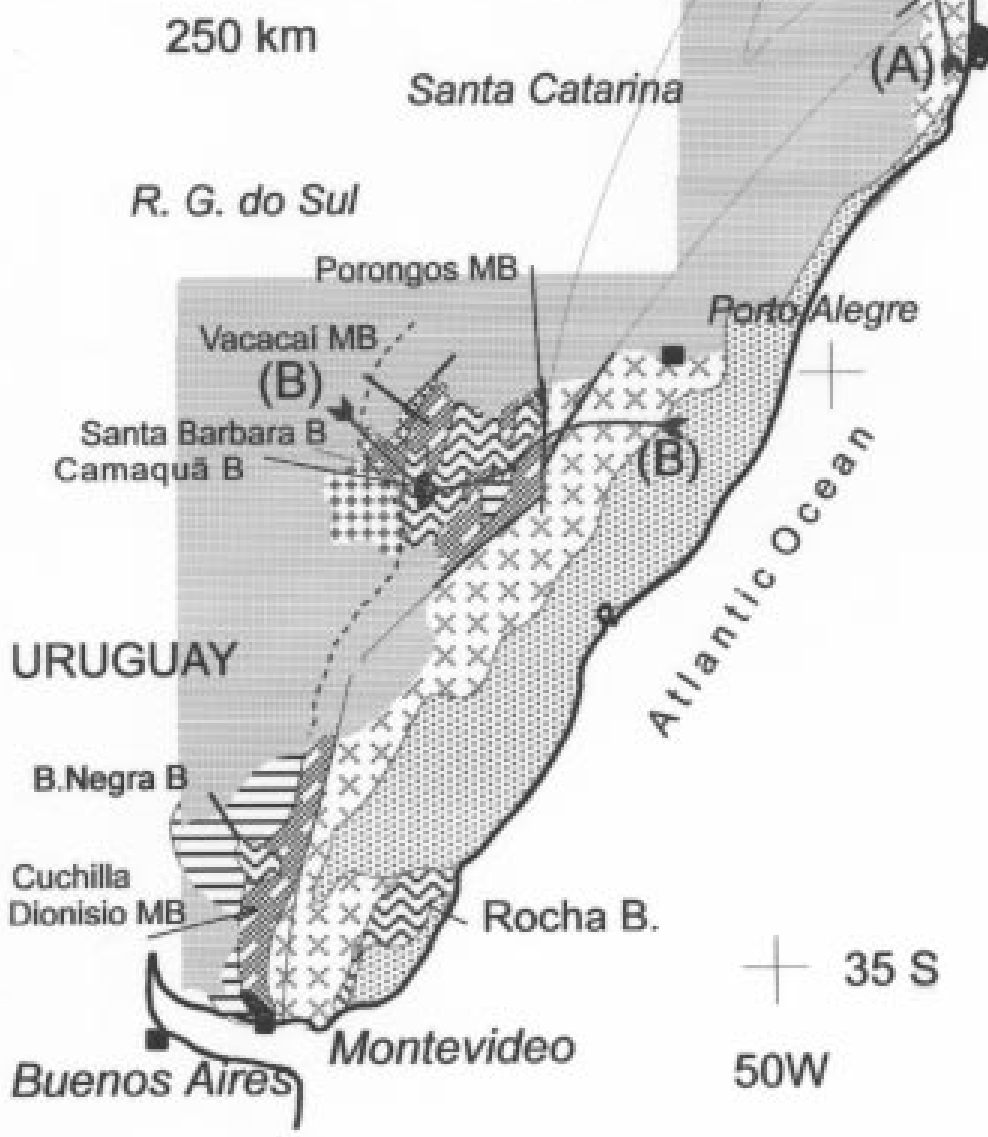

Minas Gerais

Alto Rio Grande MB

$45 \mathrm{~W}$

(Brasilia)

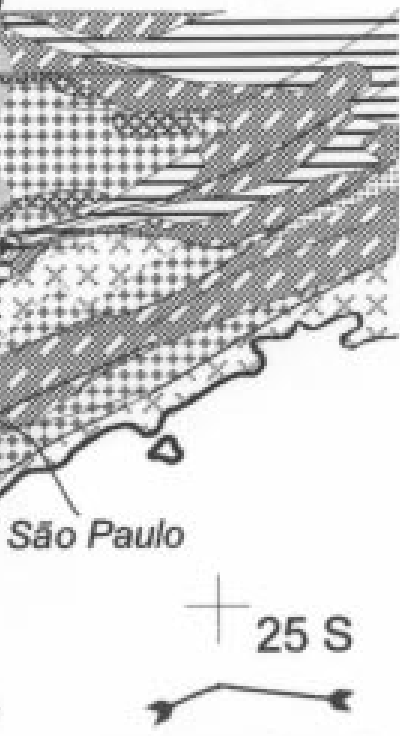

Locations of sections of figure 3

\section{Brusque MB}

Canelinha MB Florianópolis

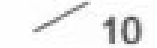




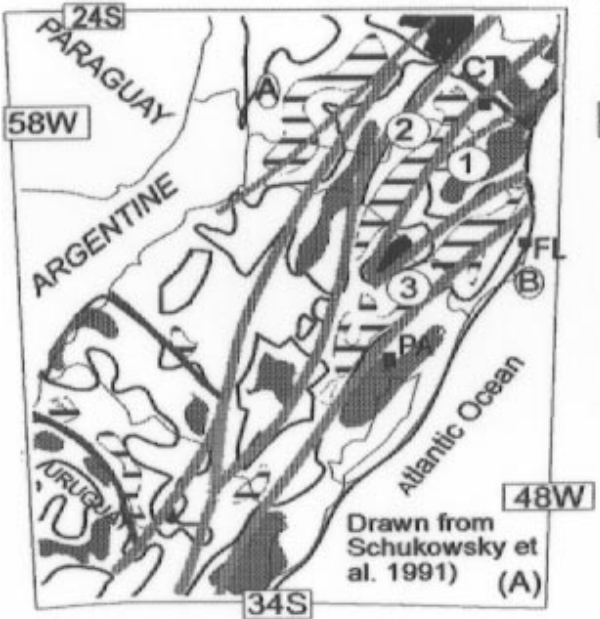

Residual values

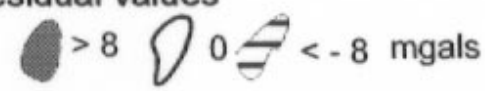

BLOCKS:

a Parana c S.Gabriel e Florida

b Curitiba dTaqarembó f Pelotas

$\mathrm{g}$ Luis Alves

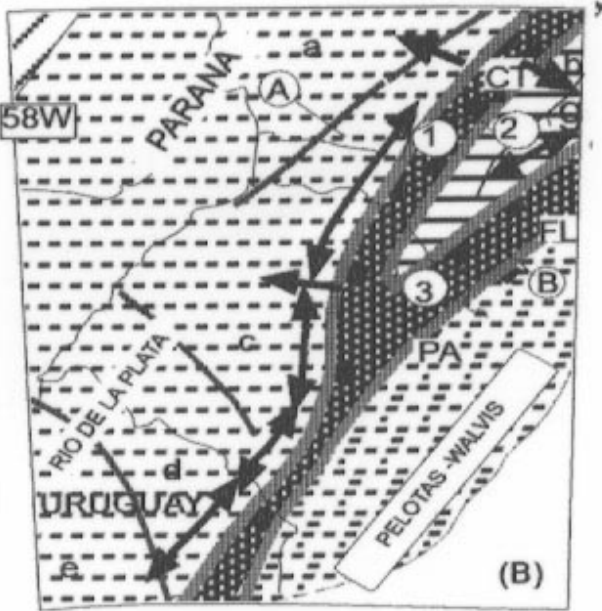

Belt boundary

Block boundary $\longrightarrow$ Frontal

bulge

\section{CITIES: CT, Curitiba}

\section{FL, Florianópolis \\ PA, Porto Alegre}

Paraná Block Ribeira belt (1) Joinville (2) Dom Feliciano Pelotas B.

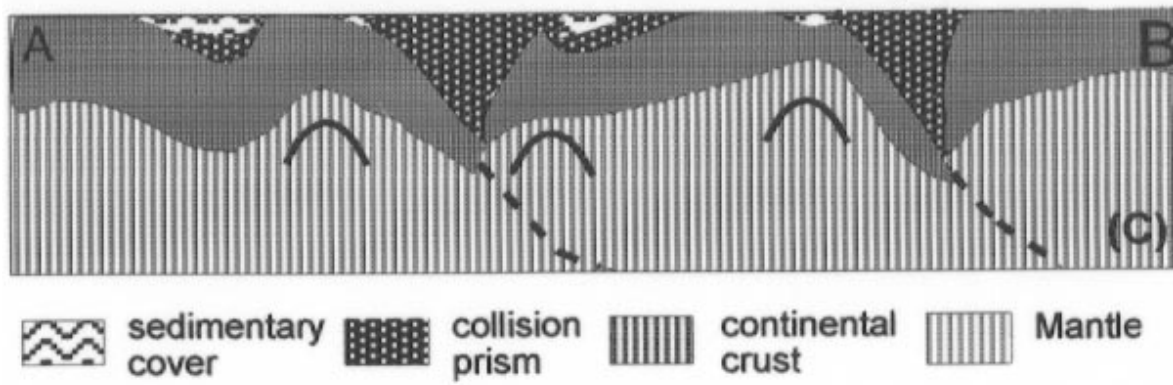

Figure 2-Extension and geometry of the Ribeira and Dom Feliciano belts, based on gravimetric and geologic data. (A) Simplified distribution of residual Bouguer gravimetric anomalies (redrawn from Schuckowsky et al. 1991). (B) collision prism delineated by low values bordered by high values at cratonic margins; (C) Diagrammatic lithosphere scale section, showing the main features of the collisional belts and crustal flexural bulges.

Árvore, Isla Patrulla and Carape unit, from north to south in the belts. These lower complexes host $\mathrm{Pb}-\mathrm{Zn}$ exhalative mineralizations. Scarce isotope data support the Mesoproterozoic age: (a) $1.4 \mathrm{Ga} \mathrm{Rb-Sr}$ age for mafic intrusions; (b) $1.2 \mathrm{Ga} \mathrm{Rb-Sr}$ age for volcanic rocks (Daitx 1995).

The Upper Metamorphic Complexes. The upper complex is dominated by phyllites, meta-quartzarenites, metapellites, stromatolitic limestones and dolostones, and turbiditic meta-wackes, with preserved primary sediment texture and structures. Three terrane types are present: a lower one made up of quartzite, phyllite, limestone and mafic intrusives and extrusives (Piririca, Saivá, Ribeirão do Ouro, Serra dos Pereiras, Cerro dos Madeiras, lower Lavalleja); an upper one made of basal ortho and paraconglomerate, below pelite-limestones sequences (São Roque, Iporanga-Lageado, upper Lavalleja-Polanco); and a third one, bearing mafic volcanics, pyroclastic rocks, limestones and conglomerates (São Roque, upper Itaiacoca, Bossoroca, Lavalleja (Valência). The metamorphism stays in the zone of the chlorite, locally biotite. The fabric is formed by a fine foliation (S2) and by oblique ductile to brittle shear foliation (C2), marking syn-metamorphic overthrust faults. By deformation style and metamorphic degree, this tectonic-metamorphic event is correlated to the D2 and M2 event of the first phase complex. The folding ( D3) affected these terranes later. Epigenetic mantle and vein type mineralizations of $\mathrm{Pb}$ and $\mathrm{Zn}$ sulfides are hosted by carbonate. A Neoproterozoic (1050 to $700 \mathrm{Ma}$ ) age is attributed, based on weak geochronologic evidences.
The folded and faulted sedimentary covers. The third rock association is made up of sedimentary terrigenous rocks, with retrograding and prograding alluvial to marine sequences. It includes the units named Pico de Itapeva (SP), Camarinha (PR), Itajaí (SC), Maricá, Boici, Mangueirão and Vargas (RS), Arroio do Soldado and Rocha (Uruguay). Volcanism was uncommon at that time. They are deformed by folds (D3), upthrusts faults and arc uplift associated to large ENE right lateral transcurrent faults (Lancinha-Cubatão and Major Gercino), and NNE-NNW left lateral (Sierra Balena and Passo do Marinheiro). Vein gold and epigenetic terrigenous $\mathrm{Cu}$ and $\mathrm{Zn}-\mathrm{Pb}$ are hosted in the group. Ichnofossils indicate a Vendian or even early Cambrian age (Gaucher and Sprechman 1998, Netto et al. 1992, Paim et al 1997).

The volcanic sedimentary complexes. The volcanic sedimentary complexes are made mainly by rhyolitic volcanic, subvolcanic and pyroclastic rocks, intertongued with continental sedimentary units are subsidiary and, in general, derived from volcanic complex sources, during active volcanism. They were deformed during and after their accumulation as tilted blocks, associated to extensional tectonic (Bonancin et al. 1994). Epithermal gold deposits are found associated with volcanic centers. Geochronologic ages for this volcanicsedimentary complexes indicate that they were formed between 600 and $480 \mathrm{Ma}$. They were formed after the Vendian covers, and are unconformably covered by late Ordovician cratonic deposits. 


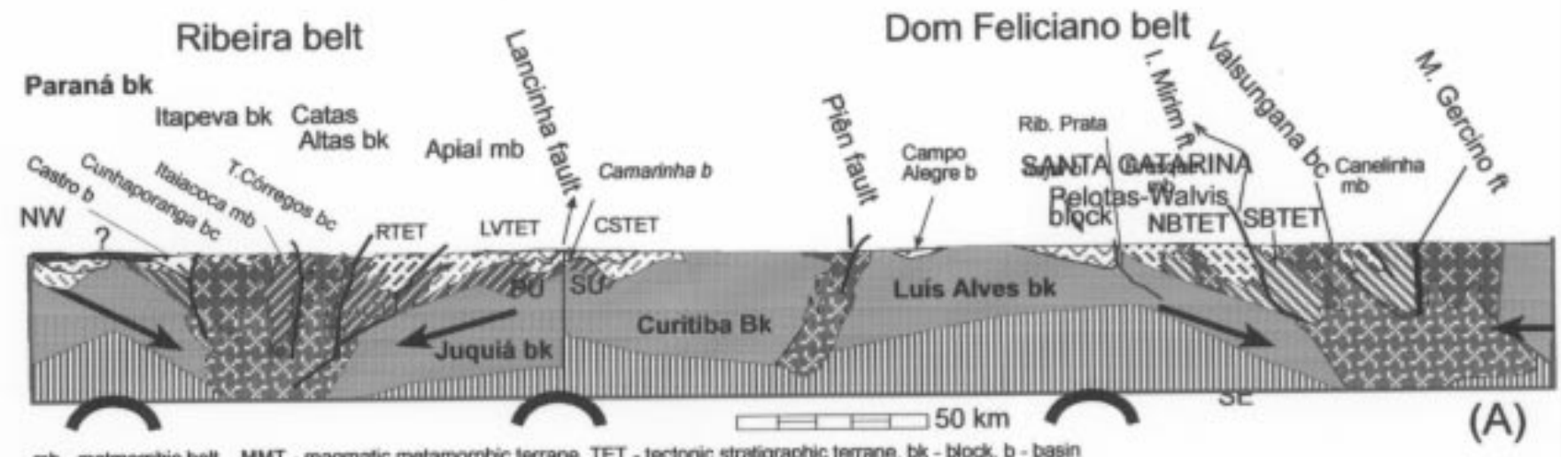

mb - metmorphic belt, MMT - magnatic metamorphic lerrane, TET - tectoric stratigraphic terrane, bk - block, b - basin Tectonic stratigraphic terranes: RTET-Rocha, LVTET - Lower Votuverava, CSTET - Capin \& Setuva, NBTET - North Busque
SBTET - South Erusque (Botuverd \& Ribeirao Ouro)

Units: ACU - Agua Clara, PU - Perau, SU - Setuve

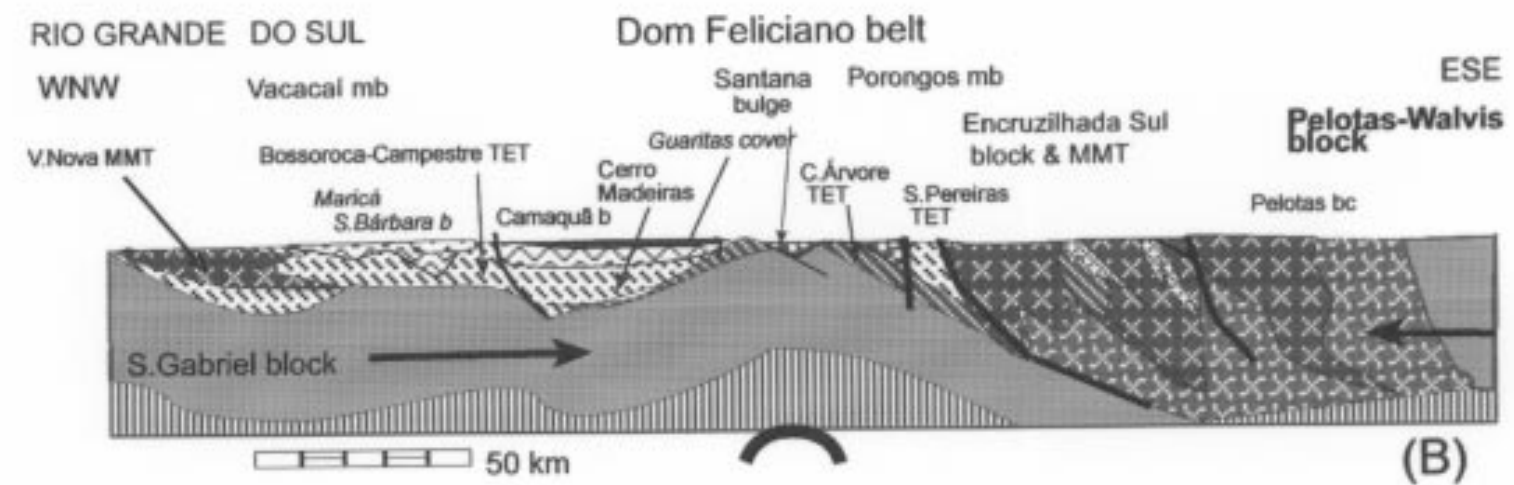

mb - metmorphic belt. MMT - magmatic metamorphic terrane, TET - tectonic stratigraphic terrane, bk - block, b- basin
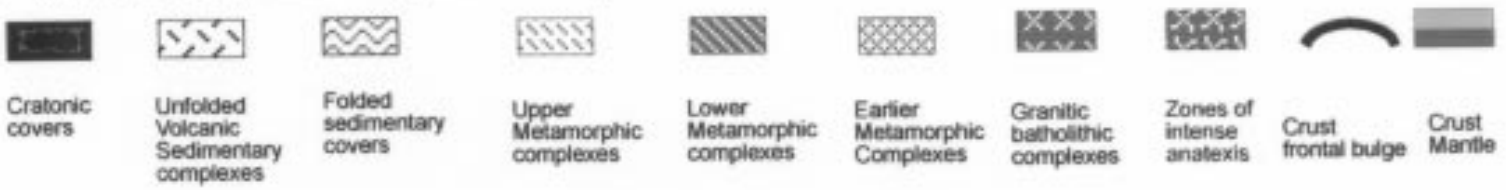

Figure 3-Geotectonic cross sections of the Neoproterozoic collision (location in Fig. 1). (A) Section representing the collision between Rio de la Plata-Paraná continent, the Joinville and the Pelotas-Walvis microcontinents. Metamorphic complexes and folded cover westward of the Cunhaporanga batholithic complex (under Paraná basin cover) is suggested by low gravimetric values and core samples in oil wells. (B) Collision between Rio de la Plata continent (São Gabriel Block) and Pelotas-Walvis microcontinent.

DISCUSSION AND CONCLUSIONS The Dom Feliciano and Ribeira belts are separated by the Joinville Paleoproterozoic-Archean continental fragment, now constituted by the Luís Alves, Curitiba and Juquiá blocks. This intermediary Joinville continental element pinches out under the Basin of Paraná, in Santa Catarina State and the two belts join in an only one belt that continues at least to Uruguay. The northeastward deflection of the São Gabriel gravimetric low make it parallel and an extension of west side of Ribeira Belt, an so the Vacacai belt is the external front of a collision metamorphic prism transported from the east suture zone (Hartmann et al. 1998).

The western margin of the Ribeira and Dom Feliciano belts is constituted by the border of the paleocontinent Rio de la Plata Paraná. The Paraná block is one part of this continent that overrode the São Francisco plate (Soares 1988), while the Ribeira belt overrode the Rio de la Plata margin. The within plate boundary between the Paraná and Rio de la Plata blocks, is made by large transcurrent fault as depicted by deep source anomalies, in magnetic and gravimetric data, and by surface geologic information around Paraná basin cover. São Gabriel and Taquarembó blocks are reworked pieces of Rio de la Plata continent (Hartmann et al. 1998); like other block boundaries (Luis
Alves, Curitiba and Juquiá), these boundaries are marked by crustal discontinuities, showing gravimetric anomalies (Sarandi del Yi, São Gabriel, Pien, Lancinha lineaments)

The oriental margin of the Dom Feliciano belt is the microcontinent Pelotas-Walvis, that intervenes among this belt and the Saldania, Gariep and Damara African belts; and not by collision between Kalahari and Rio de La Plata. The magmatic arcs were developed in the western margin of this microcontinent, explaining the crustal heritage of granites and Archean Sm-Nd age and Paleoproterozic paragnaisses pieces inside the batholith in Walvis-Windoek region.

The Mesoproterozoic tectonic stratigraphic terranes record the continental break up, rifting, formation and evolution of a continental margin within 1.4 to $1.2 \mathrm{Ga}$. The belt collapsed and its upper formations were eroded. Later on, during the Neoproterozoic (1.05 $\mathrm{Ga}$ ), new crustal stretching and basin formation occurred. The drifting of blocks generated Mediterranean basins covered by littoral deposits, grading to platform and deep starved basin, accompanied by mafic volcanics and intrusions and reaching small oceanic floor basins. Subduction proceeded and volcanic arcs were developed around 800 $\mathrm{Ma}$, after the carbonate cycle. The sedimentation evolved to back and 
$480 \mathrm{Ma}$

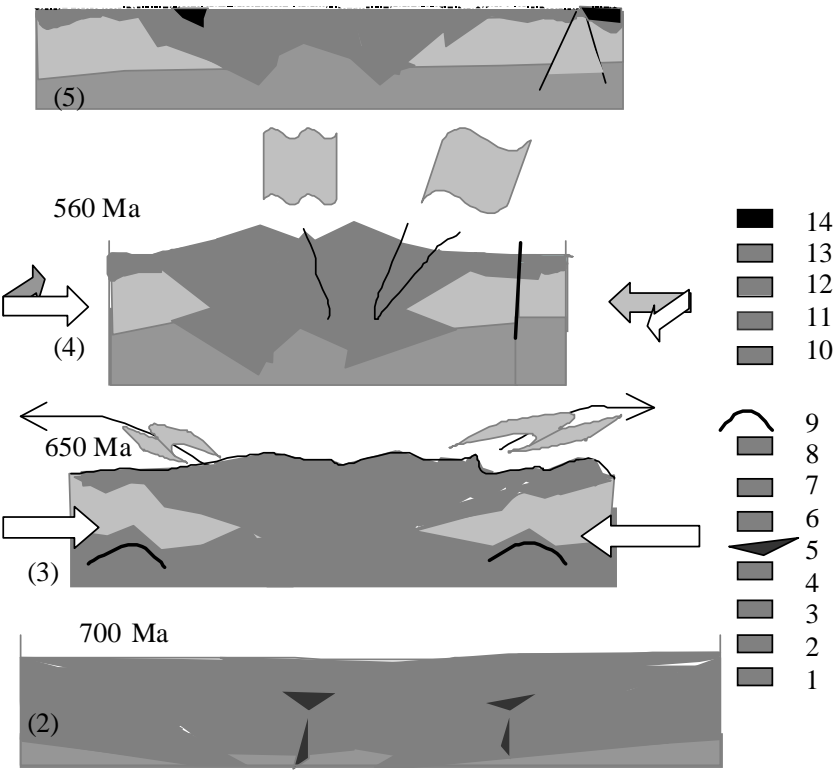

$800 \mathrm{Ma}$

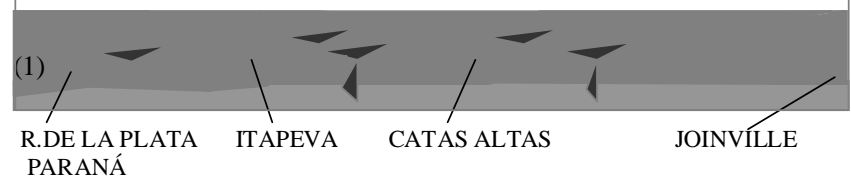

Figure 4-Cartoon view of the Ribeira belt evolution: (1) 1050-750 Ma: rifting, ocean formation and sedimentation; (2) Subduction, magmatism and inversion beginning: (3) 700-650 Ma: collision; (4) 650-560 Ma: Tectonic relaxation, erosion and basin formation and new inversion, with escape tectonics.; (5) 550-460 Ma: orogen collapse continental volcanism and sedimentation. Captions: 1. Basaltic crust; 2. Continental crust: 3. Mesoproterozoic metamorphic terranes; 4. Lower Votuverava equivalent terranes; 5. Dolerite intrusions; 6. Carbonate and mud platform sediments; 7. Volcanic and pyroclastic rocks; 8. Prograding terrigenous sandstone and shale sequence; 9. Frontal bulge; 10. Late collisional folded sedimentary cover; 11. Undifferentiated metamorphic complexes; 12. Granite-gneiss batholithic complexes; 13. Large batholithic granite intrusions; 14. Continental volcanic and sedimentary complexes. fore arc basins. The basin margin inversion occurred around 700 Ma. This interpretation is presented in cartoon view for the Ribeira belt in Paraná, in Fig. 4.

The convergence of continental terranes and closing of basins proceeded until 700-650 Ma, during continental collision. In the magmatic arc, granite gneisses (700-650 Ma) were formed and emerged, involving deeper supracrustal metamorphics of earlier cycles (mainly Mesoproterozoic units), thrusting over sedimentary and low metamorphic rocks.

Facies, thickness and geometry of Vendian basins, developed after the amalgamation of continental fragments and cratons, indicates flexural basin deepening toward the main suture zone. The thick coarsening up sequence at the top section indicates active tectonism, compression and basin fill at the and of the cycle, as well exemplified by Itajai basin (Rostirolla et al. 1999).

Large faults, mainly transcurrent ones, were developed later during and after Vendian basin filling. Profuse elongated granite intruded along faults and antiforms, indicating an age range of 600 to $550 \mathrm{Ma}$, and earlier granites were emerged in antiforms, dorsal and upside fault blocks. This movements represent the last convergence time interval with strong thermal event and geometric reorganization of metamorphic terranes and sedimentary covers to form Gondwana continent; this escape tectonic is attributed to the convex west margin of Pelotas-Walvis and Guaxupé blocks.

Many transcurrent faults of early cycle show indicators of kinematic reversion, mainly in extensional brittle regimen. Profuse granite as sharply discordant bodies, mainly of alkaline affiliation, intruded around 550-490 Ma.

Acknowledgements The authors are grateful to many people that have been in field work. Especially, we thank geologists A. Caldasso, R. Lopes, W. Wildner, from CPRM, and N. Chaves, P. Oyhantçabal, A. Heinmann, from Uruguay. Field work supported by PADCT (Finep 65.91.0303, 65. 95.0803) and by the CNPq/CNR-Italy agreement (n. 91.01.97/93-8).

\section{References}

Basei M.A.S. 1985. O Cinturão Dom Feliciano em Santa Catarina. Instituto de Geociências, Universidade de São Paulo, Ph.D. Thesis, 185 p.

Bonancin E.A, Moro R.P.X., Soares P.C. 1994. Tectônica da Bacia Ordoviciana de castro, Paraná. Bol. Par. Geoc., 42:59-72.

Daitx E.C. 1996. Origem e evolução dos depósitos sulfetados tipo Perau (Pb-Zn-Ag... (Vale do Ribeira, PR). IGCE-UNESP Rio Claro, Ph.D. Thesis, $453 \mathrm{p}$.

Fernandes L.A.D., Tommasi A., Porcher C.C. 1992. Deformation patterns in the southern brazilian branch of the Don Feliciano Belt; a reappraisal. Jour. South Am.Earth Sci., 5:77-96.

Fiori A.P. 1993. O Sistema de dobramento Apiaí Estado do Paraná. Revista Brasileira de Geociências 23(1):5-17.

Fragoso-Cesar A.R.S.1991. Tectônica de placas no ciclo brasiliano: as orogenias do cinturões Dom Feliciano e Ribeira no Rio Grande do Sul. Instituto de Geociências, Universidade de São Paulo, Ph. D. Thesis, $367 \mathrm{p}$

Gaucher C. \& Sprechmann P. 1998. Grupo Arroyo del Soldado: paleontologia, edad y correlaciones (Vendiano-cambrico Inferior, Uruguay). In: Soc. Uruguayo Geol., Congreso Uruguayo de Geologia, 2, Actas, 183-187.

Hartmann L.A., Silva L.C., Remus, M.V.D., Leite J.A.D., Philipp, R.P. 1998. Evolução Geotectônica do Sul do Brasil e Uruguai entre 3.3 Ga e 470 Ma. In: Soc. Uruguayo Geol., Congreso Uruguayo de Geologia, 2, Actas, 277-284.

Hasui Y., Carneiro C.D.R., Coimbra A. M. 1975. The Ribeira Folded Belt. Rev. Bras. Geoc., 5(4) $257-266$

Jost H. \& Bitencourt M.F. 1980. Estratigrafia e tectônica de uma fração da faixa de dobramentos Tijucas no Rio Grande do Sul. Acta Geol. Leopol. 11(7):27-59.

Juliani C. \& Beljavskis P. 1995. Revisão da litoestratigrafia da Faixa São Roque/ Serra de Itaberaba (SP). Revista IG (USP), 16(1/2):35-58.

Machado N., Koppe J.C., Hartmann L.A. 1990. A Late Proterozoic U-Pb age for the Bossoroca Belt, Rio Grande do Sul, Brazil. Jour. South Am. Earth Sci. 3(2/3):87-90.

Netto R.G., Paim.P.S., Rosa C.L.M. 1992 - Registro Preliminar da ocorrência de traços fósseis em sedimentitos das bacias de Camaquã e Santa Bárbara. I Workshop sobre as bacias molássicas brasilianas. Bol. Esp. UNISINOS, 90-97.
Paim P.S.G., Leipnitz I.I.; Rosa, A.L.Z., Rosa A.A.S. 1997. Preliminary report on the occurrence of Chancelloria sp. in the Itajaí Basin, southern Brazil. Rev. Bras. Geoc. 27(3):303-308.

Porcher C.C.\& Fernandes L.A.A. 1990. Relações embasamento/cobertura na porção ocidental do cinturão Dom Feliciano: um esboço estrutural. Pesquisas 17(1-2)72-84.

Preciozzi F., Masquelin H., Sanches L.1993. Geologia de la Porción suyr del cinturón Cuchilla Dionisio. In: DINAMIGE, Simposio Internacional del NeoproterozóicoCambrico de la Cuenca del Plata, 1, Montevideo, 3-59.

Reis Neto J.M. 1994. Faixa Itaiacoca: registro de uma colisão de dois blocos continentais no Neoproterozóico. Instituto de Geociências, Universidade de São Paulo, Ph.D. Thesis, 253p.

Reis Neto J.M. \& Soares P.C. 1987. Um estudo de caracterização termodinâmica de microestruturas dos Grupos Açungui e Setuva (PR). In: SBG, Simpósio Sul-Brasileiro de Geologia, 3, Curitiba, Atas., 1:147-165.

Rostirolla S. Arendt A. , Soares P.C., Carmignani L. 1999. Basin analysis and mineral endowment of the Proterozoic Itajaí basin, south-east Brazil. Basin Research, 11: $147-142$

Schukowsky W., Vasconcelos A.C.B.C., Mantovani M.S.M. 1991. Estruturação dos Terrenos precambrianos da região sul do Brasil e oeste do Uruguai...: um estudo por modelamento gravimétrico. Rev. Bras. Geof., 9:275-287.

Soares P.C. 1988. Tectônica colisional em torno do Bloco Paraná, Brasil. An. VII Cong. Latino-Am. Geol.. Belem, 1:63-79.

Soares P.C \& Rostirolla S.P. 1997. Tectônica de escape no cinturão Ribeira, sul do Brasil, In: Simpósio Nacional de Estudos Tectônicos, 5, Pirenópolis, Anais, 29-32.

Thomas R.J., Von Veh M.W., Mccourt S.1993. The Tectonic evolution of southern Africa: an overview. J. African Earth Sci. 16(1/2):5-24.

Contribution IGC-148 